\title{
Impact investments: a call for (re)orientation
}

\author{
Timo Busch ${ }^{1,2}$ D $\cdot$ Peter Bruce-Clark ${ }^{3}$ Jeroen Derwall ${ }^{4,5} \cdot$ Robert Eccles $^{6}$. \\ Tessa Hebb ${ }^{7}$. Andreas Hoepner ${ }^{8}$. Christian Klein ${ }^{9} \cdot$ Philipp Krueger $^{10}$. \\ Falko Paetzold ${ }^{11,2} \cdot$ Bert Scholtens $^{12} \cdot$ Olaf Weber $^{13}$
}

Received: 7 September 2020 / Accepted: 18 December 2020 / Published online: 11 January 2021

(c) The Author(s) 2021

\begin{abstract}
Practitioners and academics have been using different terms to describe investments in the sustainability context. The latest inflationary term is impact investmentsinvestments that focus on real-world changes in terms of solving social challenges and/or mitigating ecological degradation. At the core of this definition is an emphasis on transformational changes. However, the term impact investment is often used interchangeably for any investment that incorporates environmental, social, and governance (ESG) aspects. In the latter instance, achieving transformational change is not the main purpose of such investments, which therefore carries the risk of impact washing (akin to "green washing"). To offer (re-)orientation from an academic perspective, we derive a new typology of sustainable investments. This typology delivers a precise definition of what impact investments are and what they should cover. As one central contribution, we propose distinguishing between impact-aligned investments and impact-generating investments. Based on these insights, we hope to lay the foundation for future research and debates in the field of impact investing by practitioners, policymakers, and academics alike.
\end{abstract}

Keywords Financial markets · Sustainable investments · Impact generation · ESG aspects $\cdot$ Impact investing

\section{Introduction}

Regulators, asset owners, and managers increasingly ask: Do sustainable investments contribute to a better world? We use sustainable investments as a generic umbrella term for investments that incorporate environmental, social, and governance (ESG) aspects in investment decisions (Busch et al. 2016). We deliberately choose this generic term for four reasons: first, it is a well-established term in popular market

Timo Busch

timo.busch@uni-hamburg.de

Extended author information available on the last page of the article 
reports (GSIA 2019; SSF 2020) covering any type of investments that involve these aspects beyond mere risk-return considerations-independently of the scope and sophistication of this coverage. Second, the term relates to the notion of sustainable development as advocated by the United Nations (e.g., in WCED 1987). Third, in both theory and practice, sustainable investments are often referred to as social, ethical, responsible, or socially responsible investments. These terms are overlapping and complementary and have varying interpretations. We do not intend to discuss the potential differences between these terms in this paper. Fourth, the discussion of what exactly a truly sustainable investment is and what it is not is pointless. Every economic activity will potentially generate adverse environmental, social side effects, or unintended consequences. Instead, one needs to evaluate what more or less impactful investments are, an effort we explore through this contribution.

It is remarkable how the sustainable finance market and the related investing approaches have evolved over the past decades. In the early days of Sustainable Finance 1.0, the motivation was purely ethical. The focus was on exclusion criteria and avoidance of unethical behavior. This was followed by the Sustainable Finance 2.0 era, during which mainstreaming of sustainable investing in the market took place, mainly to manage financial risks. Several distinct strategies about how to use sustainability criteria within investment appraisals and sustainability-oriented indexes emerged during this time (Eccles and Klimenko 2019; Eurosif 2010). This era also focused on the interrelation between environmental, social, and financial performance, as well as the application of these approaches to large pools of assets. With environmental and social aspects now being a prominent topic in financial markets, a clear shift towards considering actual impact is observable. Especially given the Paris Agreement to limit global warming below $2{ }^{\circ} \mathrm{C}$ and the rise of the UN Sustainable Development Goals (SDGs), we see this as the advent of Sustainable Finance 3.0. This re-orientation towards impact in financial markets is a significant change and challenge. It changes sustainable finance from the business case of sustainability to the sustainability case of business that asks for positive impacts of finance (Weber and Feltmate 2016). It poses new questions and brings ample opportunities for all stakeholders. The biggest challenge is that with any ESG consideration, the unit of analysis is the performance of the firm. However, incorporating impacts requires considering positive and negative externalities.

We define impact investments as investments that focus on real-world changes in terms of solving social challenges and/or mitigating ecological degradation. Official numbers published by major networks in the impact field document a substantial market-size growth in recent years (GSIA 2019). Respondents to the latest annual GIIN (2019a) survey reported USD 239 billion in assets as impact investments. The overall size of the impact investment market is estimated to be about USD 502 billion (GIIN 2019b). At the same time, these numbers raise the question of what is actually considered an impact investment.

The risk of impact washing is an impediment to impact investing becoming a widely practiced success story (Harji and Jackson 2012; Findlay and Moran 2019). We define impact washing as the dilution of the term impact investing using the term impact as a marketing tool to attract capital or boost reputations without actually focusing on material solutions to environmental and societal challenges. Many 
sustainability-oriented investors currently rely on the data provided by sustainability rating agencies. While utilizing these data is certainly an important way of reflecting on environmental and social aspects in investment appraisals, this behavior is not at the core of what impact-generating investments should involve. More recently, the term impact investing has emerged in the listed equity space. The question now arises about how the increasing crowd of investors who label their investments as impact investments can actually make a positive contribution to real-world changes. Those who do not precisely analyze their investments beyond the scope of environmental and social considerations run the risk of falling victim to accusations of impact washing.

Thus, a key question in the Sustainable Finance 3.0 era is: Which investments are real-impact investments and which investments are not? In the 1980s and 1990s, several impact-related investment products, such as microfinance funds, were launched. In the academic literature, Munoz-Torres et al. (2004) were among the first authors to investigate the non-financial performance of sustainability-related funds. Brest and Born (2013: 24) referred to the practice of impact investing as "actively placing capital in enterprises that generate social or environmental goods, services, or ancillary benefits." Since then, several impact investment definitions and extensions have emerged in the academic literature and practitioner contributions. We intend to advance this debate in two main regards. First, we review the development of the sustainable finance market over the last decades and highlight the distinct investment philosophy of impact investments. Second, we present a new typology of sustainable investments. This typology delivers a precise definition of what impact investments are and what they should cover to have an impact-generating effect. Based on these insights, we hope to lay the foundation for future research and debates in the field of impact investing by practitioners, policymakers, and academics alike.

\section{From Sustainable Finance 1.0 to Sustainable Finance $\mathbf{3 . 0}$}

We frame Sustainable Finance 1.0 as the starting phase in which financial actors initially started considering financial markets and investments to be connected to social challenges and ecological degradation. Its roots can be traced back 3500 years to when investors first started to align their actions with the Jewish belief system (Louche et al. 2012); in the mid-1700s, the Methodist Church established similar principles (Camilleri 2017). The Quakers instituted exclusion criteria for their investments to avoid supporting or engaging in the slave trade, which they deemed abhorrent in light of their religious beliefs. This approach of screening portfolios, based on exclusion criteria or engaging in socially responsible investment (SRI) as the practice became known-gained greater prominence during divestment campaigns, in particular in the US in the wake of the Vietnam War, as well as campaigns implemented by US universities to challenge Apartheid in South Africa in the 1970s and 1980s (Molthan 2003; Hunt et al. 2017). Exclusion criteria are applied to this day, as illustrated, for example, by the recent and ongoing divestment campaigns that shun fossil fuel investments. Even some of the largest fortunes created by oil, 
such as the Government Pension Fund of Norway or the Rockefeller Brothers Fund, have publicly declared their carbon divestment strategies (New York Times 2014).

All the efforts in this first phase have had one common purpose: to deter individual investors from investing in firms that practice non-sustainable or non-ethical activities. In this sense, investors bring their responsibility into focus by refraining from financially supporting undesirable business activities. Changing the business activities in question is not the prime objective of this approach, although it could be a consequence if a significant number of investors follow suit. For example, the public awareness raised by divestment campaigns in the context of Apartheid in South Africa successfully affected US public policy. In 1986, the US Congress overrode President Ronald Reagan's veto to enact the Comprehensive Anti-Apartheid Act, which included substantial economic sanctions that drove many multinational firms away from South Africa, including an official ban on new US investments and loans in South Africa (US Congress 1986).

In the next era, Sustainable Finance 2.0, the term ESG was coined, summarizing the concept of measuring the environmental, social, and governance performance of investable firms, and considering the resulting rating scores when choosing to avoid, prioritize, or discount investments based on that ESG data (see, e.g., The Global Compact 2004). Emphasizing the notion that ESG data are relevant not only from an ethical perspective but also from a financial perspective, sustainability became increasingly relevant in mainstream financial markets. This especially holds for the "G" or "Governance" in ESG data. However, governance characteristics, like board size, tenure, committees et al., cover firm-individual aspects and are not directly related to global sustainability challenges, as depicted, for example, by the planetary boundaries (Rockström et al. 2009). Several distinct strategies emerged around the use of sustainability for investment purposes (Eccles and Klimenko 2019). Initially, the European Social Investment Forum referred to six sustainable investment strategies: exclusions, positive/norms-based screening, best-in-class approach (e.g., screening relative to industry peers), sustainability-themed investing, ESG integration, and active ownership (engagement and voting) (Eurosif 2010). Impact investments were added as a new investment strategy for the first time in the 2012 market report (Eurosif 2012).

In response to the increasing relevance of and demand for environmental and social data from the 1980s onwards, specialized data and rating providers were launched, such as KLD, Innovest and GMI Ratings in the US, Oekom Research in Germany, Eiris in the UK, and Arèse (later acquired by Vigeo) in France. Over the last decade and with a recent peak, this fairly new market segment has experienced a substantial consolidation, which has given rise to large market players, such as Sustainalytics, MSCI ESG, ISS ESG, and Vigeo Eiris (Eccles and Stroehle 2018). The growth of these data providers was accompanied by the launch of sustainabilityoriented indices, such as the Dow Jones Sustainability Index in 1999, and the initiation of large ESG-based funds managed by, for example, firms, such as Dexia AM, Sarasin, SAM, Pictet, or F\&C.

Some distinctive features describe this second phase. Many actors in financial markets claimed that new ecological and social risks were on the rise and that sustainable investments could help investors mitigate these risks. Furthermore, in the 
academic world, the doing well by doing good debate commenced. The majority of the extant literature contributing to this debate concludes that sustainable investments are, on average, not related to negative financial performance implications (Friede et al. 2015; von Wallis and Klein 2015). One common claim of this second phase of sustainable finance emphasizes that ethical investing needs to leave its niche status behind and become mainstream practice in financial markets. Recent market data reveal that, over time, more and more asset owners and managers have included ESG data considerations in their investment decision-making processes (GSIA 2019). As such, the "ESG [movement] has done what traditional socially responsible investing could not: ESG has breached the wall that isolated mainstream investing from socially responsible investing" (Bailard Wealth Management 2017, p. 3). However, some doubt remains whether considering environmental and social indicators changed financial decisions at all. Some argue that, in the end, financial arguments win over environmental or social considerations (Weber and Feltmate 2016).

By Sustainable Finance 3.0, we refer to a substantial re-orientation toward impacts in financial markets. While Sustainable Finance 1.0 can mainly be ascribed to an individual investor's responsibility standpoint, and the topic successfully became an important part of the mainstream financial market during the course of Sustainable Finance 2.0, a key aspect was mostly neglected during these phases: Do investments in the sustainability context contribute to a better world? This idea requires investors to trigger a material change in a company's environmental and social performance (Kölbel et al. 2019).

In a review of the extant literature, it is clear that impact investing is not a wellspecified construct, with overlapping understandings and blurred boundaries representing different perspectives from various interest groups (Daggers and Nicholls 2016). Typical classification schemes for different sustainable investment strategies highlight impact investments as a distinctive investment approach (O'Donohoe et al. 2010). This approach is often understood as impact first, as opposed to finance first, meaning that investors first ensure that an investment provides an additional positive impact in the real world before considering its financial aspects (Feidrich and Fulton 2009). As such, this investment strategy seeks to explicitly address the impact of an investment. Simultaneously, a growing number of impact labeled investments follow the formulaic thinking that ESG investing equals impact investing — clearly portraying the risk of impact washing since achieving change is not the main purpose of ESG investments. The crucial difference is that impact investment has explicit environmental and social performance objectives, next to financial performance objectives. As such, we argue that putting real impacts-i.e., solving social challenges and/or mitigating environmental degradation - at the center of the debate is the main change required if we are to move forward from Sustainable Finance 2.0 to Sustainable Finance 3.0.

\section{A new impact investment framework}

As a point of departure, any sustainability-related investment can utilize the Darmstadt Definition of Sustainable Investments (Hoffmann et al. 2004) to derive a general investment philosophy and motivation. This definition lays out an ideal-typical 
orientation of a sustainable investment from a holistic point of view. For example, from an economic perspective, this includes profits accrued on the basis of longterm production and investment strategies and not based on corruption. An ecological perspective can, for example, focus on increasing resource productivity or the recycling and reuse of used materials and substances. Finally, profit-making should be consistent with the development of human, social, and cultural capital.

Based on this general understanding of what any sustainable investment ideally comprise, we propose a typology of four distinct dimensions along which investments can be distinguished (Table 1). First, ESG-screened investments can be interpreted as investments requiring the minimum effort and start with any consideration of $\mathrm{E}, \mathrm{S}$, or $\mathrm{G}^{1}$ factors within investment appraisals. These investments typically focus on exclusion criteria. The underlying objective of such investments is the mitigation of ESG-related risks and/or ethical considerations. Second, ESG-managed investments go one step further and incorporate a comprehensive set of exclusion criteria, and at least one other pre-investment decision approach is applied, including normsbased screening, best-in-class, ESG integration, or thematic funds. For these investments, the underlying strategic purpose is a systematic reflection on ESG-related risks and opportunities. In comparison to ESG-screened investments, ESG-managed investments provide customers with a basic description of their investment appraisal and should be externally verified, e.g., by an audit or label.

In addition to these investments, we distinguish two types of impact-related investments. We argue that impact investments should be separated into impactaligned investments and impact-generating investments. While impact-aligned investments apply a comprehensive set of exclusion criteria and combine at least one pre- and one post-investment decision approach, impact-generating investments may use different strategies. For an active contribution to social and environmental solutions and transformations, we propose three general mechanisms: first, investors can provide additional capital that allows firms or projects to generate a social and/or environmental impact. Second, investors can focus on firms that establish forwardlooking targets towards impact generation. Third, investors can prompt firms to change by effectively utilizing the two post-investment decision approaches: voting and engagement regarding social and environmental issues, using clear milestones.

Both types of impact-related investments provide and require proof of social and/ or environmental materiality, not the materiality notion used in accounting. Thus, we define materiality as the measurement of tangible real-world parameters in the social and/or environmental realm. This measurement pertains to significant improvements based on sustainability performance indicators, such as greenhouse gas (GHG) emissions or gender representation on corporate boards of directors. We propose the following differentiation between the two types of impact-related investments: for impact-aligned investments, materiality is provided through detailed descriptions of

\footnotetext{
1 We acknowledge that the dimensions for governance $(\mathrm{G})$ are very different compared to those for environmental (E) and social (S) aspects. For example, most shareholder petitions typically relate to governance aspects while this is less the case for E/S aspects. Nevertheless, we use the ESG terminology here since this is the established term in financial markets.
} 


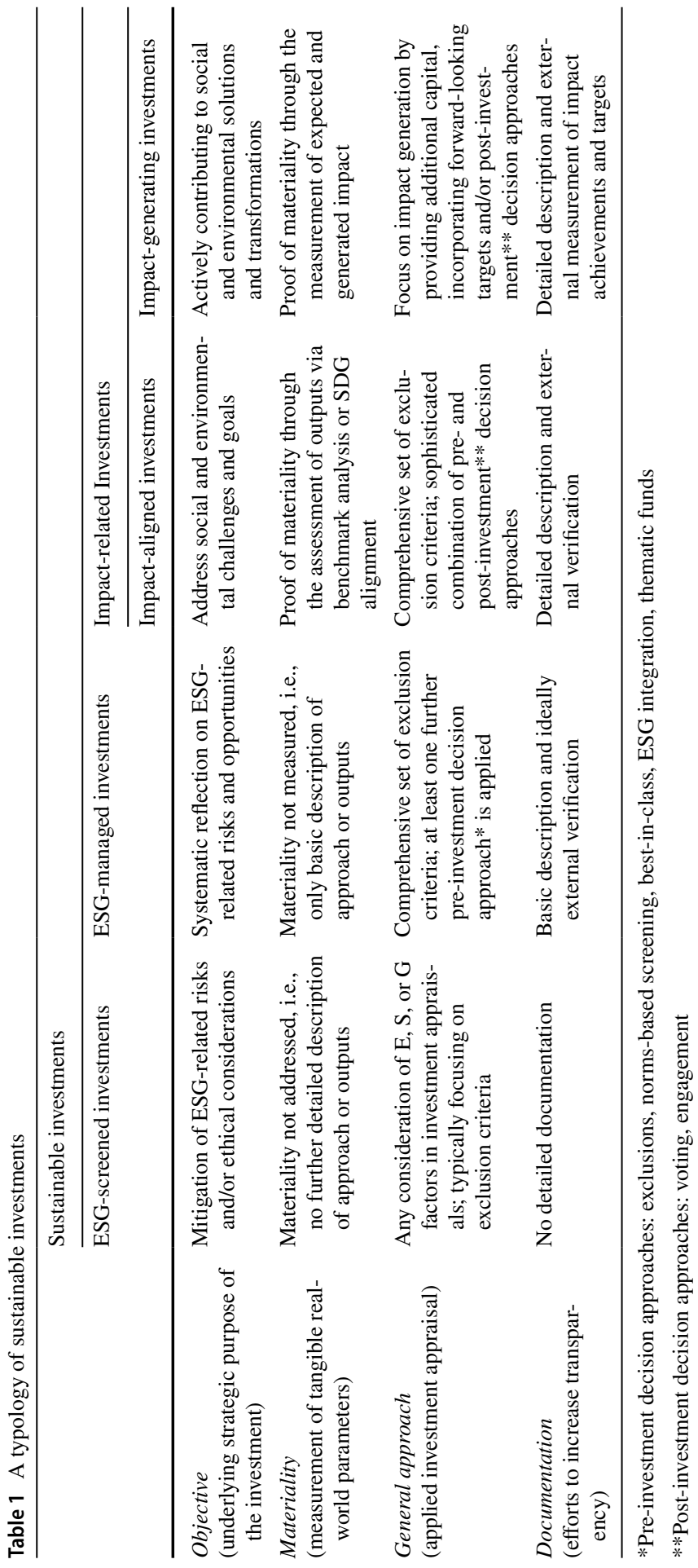


already realized outputs via benchmark analysis or the level of SDG alignment. Outputs are defined as the results of an investment strategy that can be measured (Clark et al. 2004). For impact-generating investments, materiality is provided by measuring the further impact that is being generated or will be achieved. In other words, for an investment to be impact-generating, there must be an apparent causal effect on an outcome that can be attributed to the underlying investment made. For example, an impact-aligned fund would illustrate that the investment portfolio's level of GHG emissions is $50 \%$ less than the level of emissions compared to an adequate reference benchmark. For instance, an impact-generating fund could demonstrate that through microfinance investments in India, 1000 tons of GHG are reduced. However, more research is needed to allocate and benchmark impacts to investments-for instance, to avoid double-counting by allocating impacts of projects to both impact investors and the project. Concerning benchmarking, one problem is that a 20 percent reduction of GHG emissions of a big investment fund may translate into a more considerable decrease in total emissions than the 100 percent carbon-free portfolio of a small green investment fund by a specialized impact investor.

\section{Discussion}

ESG-screened and ESG-managed investments in public markets (debt or equity), or even mid- to late-stage private equity, is a retroactive and retrospective activist investment management strategy but is not typically geared towards fundamentally changing what pre-existing companies produce as goods or services. These managed investments are more about supply chain management, business function management, and governance (i.e., executive management) across environmental, societal, and internal employee governance and management. As such, there are no efforts towards initiating or achieving further real-world changes.

By contrast, impact-related investments focus on (typically) fledgling companies that are transforming or disrupting an existing industry or market across environmental or social areas, or they focus on creating entirely new markets and industries through the application of novel technologies. With the latter, impacts can be in-built to the business model. The main difference between the two impact-related investment types is whether investors invest in companies that have already changed and now perform better than a reference benchmark or whether the investment triggers-i.e., generates - a (further) change. One option in this latter regard is to construct portfolios comprising of firms with clear change objectives. To be investable, firms can, for example, quantify their intended contribution to specific SDG subtargets or commit to science-based targets.

Many studies and investors claim that investments in private markets have the highest potential to generate impact (e.g., Braak-Forstinger and Selian 2020). Investors can generate impact in private markets by allocating capital to (typically) young companies that could grow but only have limited access to external financing. Take, for example, any startup that addresses an important sustainability challenge and requires new funding - often in the form of venture capital or private equity - to expand its business. In public markets, pure equity-focused investors can also pursue 
an active strategy towards achieving change through active ownership. First, at the managerial level, investors can generate impact by encouraging change in wellestablished firms. Based on engagement strategies, they can individually use their voices as shareholders to convince companies to change gears and to improve their production processes or products. Second, investors can join coalitions and cooperate with other investors on prominent issues, such as human rights violations or climate change (Chen et al. 2020; Dyck et al. 2019). Through huge coalitions, investors can start movements that can incentivize companies to change their strategies. The advantage of such coalitions is that the causal mechanism of the engagement efforts becomes clear.

In the impact investment literature (Brest and Born 2013; Findlay and Moran 2019), two other determinants of impact investments are discussed: intentionality and additionality. We omit both from our typology since their implementation and documentation appear to be difficult to specify and questionable from both an investment and social-environmental perspective. Moreover, both determinants may be the source of many issues and confusion that have confronted the impact investment market in the past.

With respect to intentionality, we see three possible intentions underlying a sustainable investment. First, investors may hope to achieve better financial performance or to reduce risks. Second, they exclude certain investments because of personal values or norms. Third, they hope that their investment will change the economy and/or society in a direction they deem desirable, which would promote the notion of impact investment. From an investor's perspective, intentionality primarily encompasses the investor's intent; investee intent can be seen as an additional underlying component (Findlay and Moran 2019). However, despite the empirical evidence that social preferences drive the demand for sustainable investments (Bauer et al. 2019), any intentions are unobservable. We can only see the revealed preferences of the investors because an equilibrium outcome on the market is the result of the supply of and the demand for particular financial assets with diverse attributes. As such, any reference to intentionality remains speculative-even if it is prominently stated and proclaimed. Therefore, the objective of any sustainabilityrelated investment should be documented and made transparent; this captures the investment's underlying strategic purpose.

With respect to additionality, the typical claim is that an impact investment has to be an investment in the real economy that would not have otherwise happened. In this perspective, it is important that the financing generates an impact and that the investment itself would not have occurred without this source of funding. As a major consequence, proponents of additionality argue that an investment that can be financed at normal market conditions will also be made without sustainable finance. As such, additionality assumes that the investor is willing to or is convinced to invest at non-market conditions and that the investor generally accepts poorer financial performance (Barber et al. 2021), i.e., an inferior risk-return ratio. That is indeed the case with several investors, particularly in the microfinance field. However, in most investment cases, additionality remains a problematic criterion. Where investments are an intermediary service and made in an open and competitive market, additionality is hard to prove. Therefore, we 
abstain from the idea of additionality and emphasize that the major feature of real-impact investments is impact generation, independently of financial performance considerations.

\section{Conclusion}

Financial markets experienced a substantial mainstreaming of sustainabilityrelated investment practices in recent years. Now it is the time to put impact at the center of the debate. In many cases, impact investments are simply seen as a new framing for what has already been happening. But impact does not equal ESG. We call for a re-orientation of what impact investments are: impact-aligned investments address social and environmental challenges and goals. Product specifications provide a detailed description of how an investment has achieved a better social and/or environmental performance in the past, relative to a benchmark, and how the investment contributes to the SDGs. To be impact-aligned, no (further) investment-induced change in the real world needs to be a prerequisite. In contrast, investment-induced change is at the core of impact-generating investments. The objective of these investments is to contribute to-i.e., generate and accelerate-solutions to environmental and societal challenges and, thus, to the required transformation of the economy. While providing proof and the causal mechanism of such an impact-generating effect may often remain challenging, specifically in public markets, the full leverage potential of financial markets for more sustainable development will be revealed by focusing on impact generation.

We hope that with this call for (re-)orientation, we can add an important angle for the remaining impact journey in the Sustainable Finance 3.0 era. Specifically, the current regulatory efforts by the EU Commission regarding sustainabilityrelated disclosures in the financial services sector may benefit from a precise and applicable definition of what impact-aligned and -generating investments are and what they are not. The proposed typology helps to mitigate impact washing criticisms, and it provides investors and beneficiaries a better understanding of what to expect from each type of investment. Looking ahead, the main challenge for all involved actors in the field remains a standardized framework for determining and measuring real-world impacts. We consider our contribution an important starting point for this endeavor.

Acknowledgements The authors would like to thank several colleagues from the Research Group on Sustainable Finance in Hamburg, Germany, and Roland Koelsch and Maro Wilkens for fruitful discussions and helpful feedback during the course of developing this manuscript.

Funding Open Access funding enabled and organized by Projekt DEAL.

Data availability Not applicable since this is not an empirical paper. 


\section{Compliance with ethical standards}

Conflict of interest The corresponding author states that there is no conflict of interest.

Open Access This article is licensed under a Creative Commons Attribution 4.0 International License, which permits use, sharing, adaptation, distribution and reproduction in any medium or format, as long as you give appropriate credit to the original author(s) and the source, provide a link to the Creative Commons licence, and indicate if changes were made. The images or other third party material in this article are included in the article's Creative Commons licence, unless indicated otherwise in a credit line to the material. If material is not included in the article's Creative Commons licence and your intended use is not permitted by statutory regulation or exceeds the permitted use, you will need to obtain permission directly from the copyright holder. To view a copy of this licence, visit http://creativecommons.org/licen ses/by/4.0/.

\section{References}

Bailard Wealth Management (2017) The origins of socially responsible and sustainable investing. Bailard Wealth Management, Foster City, California

Barber BM, Morse A, Yasuda A (2021) Impact investing. J Financ Econ 139:162-185

Bauer R, Ruof T, Smeets P (2019) Get real! Individuals prefer more sustainable investments. SSRN: https ://papers.ssrn.com/sol3/papers.cfm?abstract_id=3287430

Braak-Forstinger C, Selian A (2020) How to increase family office engagement in impact investing. Bertelsmann Stiftung, Gütersloh

Brest P, Born K (2013) When can impact investing create real impact. Stanford Soc Innov Rev 11(4):22-31

Busch T, Bauer R, Orlitzky M (2016) Sustainable development and financial markets: old paths and new avenues. Business Soc 55(3):303-329. https://doi.org/10.1177/0007650315570701

Camilleri MA (2017) Socially responsible and sustainable investing. In: Camilleri MA (ed) Corporate sustainability, social responsibility and environmental management. Springer International Publishing, Cham, pp 61-77

Clark C, Rosenzweig W, Long D, Olsen S (2004) Double bottom line project report: assessing social impact in double bottom line ventures. University of California, Berkeley: Center for Responsible Business

Chen T, Dong H, Lin C (2020) Institutional shareholders and corporate social responsibility. J Financ Econ 135(2):483-504

Daggers J, Nicholls A (2016) The landscape of social impact investment research: trends and opportunities. Said Business School, Oxford

Dyck A, Lins KV, Roth L, Wagner HF (2019) Do institutional investors drive corporate social resposnbility? International evidence. J Financ Econ 131(3):693-714

Eccles RG, Stroehle J (2018) Exploring social origins in the construction of ESG measures. SSRN Electron J. https://doi.org/10.2139/ssrn.3212685

Eccles RG, Klimenko S (2019) The investor revolution. Harvard Business Rev 97(3):106-116

Eurosif (2010) European SRI Study 2010. Retrieved from Paris https://www.eurosif.org/wp-content/ uploads/2014/04/Eurosif_2010_SRI_Study.pdf. Accessed 1 Dec 2020

Eurosif (2012) European SRI Study 2012. Retrieved from Brussels https://www.eurosif.org/wp-content/ uploads/2014/05/eurosif-sri-study_low-res-v1.1.pdf. Accessed 1 Dec 2020

Feidrich J, Fulton K (2009) Investing for social and environmental impact. A catalyst for an emerging industry. The Monitor Institute. https://arthaimpact.com/wp-content/uploads/2019/09/9dadf 9e0-d8fb-4f80-b75d-54da84821802_17.pdf. Accessed 1 Dec 2020

Findlay S, Moran M (2019) Purpose-washing of impact investing funds: motivations, occurrence and prevention. Soc Responsib J 15(7):853-873

Friede G, Busch T, Bassen A (2015) ESG and financial performance: aggregated evidence from more than 2000 empirical studies. J Sustain Financ Invest 5:210-233. https://doi.org/10.1080/20430 795.2015 .1118917 
GIIN (2019a) Annual impact investor survey 2019: Global Impact Investing Network https://thegiin.org/ research/publication/impinv-survey-2019 Accessed 2 Dec 2020

GIIN (2019b) Sizing the impact investment market: Global Impact Investing Network https://thegiin.org/ research/publication/impinv-market-size Accessed 2 Dec 2020

GSIA (2019) Global sustainable investment review 2018: global impact investing network

Harji K, Jackson ET (2012) Accelerating impact. Achievements, challenges and what's next in building the impact investing industry. The Rockefeller Foundation. Retrieved from New York: https://www. rockefellerfoundation.org/wp-content/uploads/Accelerating-Impact-Full-Summary.pdf. Accessed 1 Dec 2020

Hoffmann J, Scherhorn G, Busch T (2004) Darmstadt definition of sustainable investments. Retrieved from Wuppertal: https://www.econstor.eu/bitstream/10419/59280/1/484957511.pdf. Accessed 1 Dec 2020

Hunt C, Weber O, Dordi T (2017) A comparative analysis of the anti-Apartheid and fossil fuel divestment campaigns. J Sustain Financ Invest 7(1):64-81. https://doi.org/10.1080/20430795.2016.1202641

Kölbel J, Heeb F, Paetzold F, Busch T (2019) Can sustainable investing save the world?: Reviewing the mechanisms of investor impact. Org Environ. https://doi.org/10.1177/1086026620919202

Louche C, Arenas D, van Cranenburgh KC (2012) From preaching to investing: attitudes of religious organisations towards responsible investment. J Bus Ethics 110:301-320. https://doi.org/10.1007/ s10551-011-1155-8

Molthan P (2003) Introduction. In: Broadhurst D, Marshall J, Watson J (eds) Ethical and socially responsible investment: a reference guide for researchers. K.G Saur, München, pp 11-25

Munoz-Torres MJ, Fernandez-Izquierdo MA, Balaguer-Franch MR (2004) The social responsibility performance of ethical and solidarity funds: an approach to the case of Spain. Bus Ethics Eur Rev 13(2/3):200-218

New York Times (2014) Rockefellers, heirs to an oil fortune, will divest charity of fossil fuels. New York Times. https://www.nytimes.com/2014/09/22/us/heirs-to-an-oil-fortune-join-the-divestment-drive .html

O’Donohoe N, Leijonhufvud C, Saltuk Y (2010) Impact investments. An emerging asset class. J.P.Morgan: https://www.rockefellerfoundation.org/wp-content/uploads/Impact-Investments-AnEmerging-Asset-Class.pdf. Accessed 1 Dec 2020

Rockström J, Steffen W, Noone K, Persson A, Chapin FS, Lambin EF, Foley JA (2009) A safe operating space for humanity. Nature 461(7263):472-475. https://doi.org/10.1038/461472a

Swiss Sustainable Finance (2020) Swiss Sustainable investment market study 2020. Swiss Sustainable Finance, Zurich

The Global Compact (2004) Who cares wins. Connecting financial markets to a changing world. https:// www.ifc.org/wps/wcm/connect/topics_ext_content/ifc_external_corporate_site/sustainability-at-ifc/ publications/publications_report_whocareswins_wci_1319579355342

US Congress (1986) Comprehensive anti-apartheid act of 1986

UNCTAD (2014) World investment report 2014-investing in the SDGs: an action plan. United Nations, New York and Geneva

von Wallis M, Klein C (2015) Ethical requirement and financial interest: a literature review on socially responsible investing. Bus Res 8:61-98

WCED (1987) Our common future. World commission on environment and development, Oxford University Press, Oxford

Weber O, Feltmate B (2016) Sustainable banking: managing the social and environmental impact of financial institutions. University of Toronto Press, Toronto

\section{Affiliations}

\section{Timo Busch ${ }^{1,2}$ (1) Peter Bruce-Clark ${ }^{3}$. Jeroen Derwall ${ }^{4,5} \cdot$ Robert Eccles $^{6}$. Tessa $\mathrm{Hebb}^{7}$. Andreas Hoepner ${ }^{8}$. Christian Klein ${ }^{9}$. Philipp Krueger ${ }^{10}$. Falko Paetzold ${ }^{11,2} \cdot$ Bert Scholtens $^{12}$. Olaf Weber ${ }^{13}$}

1 University of Hamburg, Hamburg, Germany 
2 University of Zurich, Zurich, Switzerland

3 Social Impact Capital, New York, USA

4 Maastricht University, Maastricht, The Netherlands

5 Utrecht University, Utrecht, The Netherlands

6 University of Oxford, Oxford, UK

7 Carleton University, Ottawa, Canada

8 University College Dublin, Dublin, Ireland

9 University of Kassel, Kassel, Germany

10 University of Geneva, Swiss Finance Institute, Geneva, Switzerland

11 EBS University, Oestrich-Winkel, Germany

12 University of Groningen, Groningen, The Netherlands

13 University of Waterloo, Waterloo, Canada 